UDC 615.32

\author{
I.V. Semeniuk ${ }^{a}$, V.V. Kocubei ${ }^{b}$, O.Ya. Karpenko ${ }^{b}$, H.H. Midyana ${ }^{a}$, O.V. Karpenko ${ }^{a}$, \\ V.V. Serheyev ${ }^{b}$
}

\title{
STUDY OF THE COMPOSITION OF HUMIC ACIDS OF DIFFERENT ORIGINS
}

\author{
a Department of Physical Chemistry of Fossil Fuels of the L.M. Lytvynenko Institute of Physical-Organic \\ Chemistry and Coal Chemistry of National Academy of Sciences of Ukraine, Lviv, Ukraine \\ ${ }^{\text {b }}$ Lviv Polytechnic National University, Lviv, Ukraine
}

\begin{abstract}
Thermal, titrimetric analysis and UV/Vis spectroscopy were used to study the structural features of molecules of humic acids prepared from different raw materials, such as biohumus, peat, brown coal, and chernozem. Humic acids were extracted from these material by aqueous solutions of potassium hydroxide at the temperature of $50^{\circ} \mathrm{C}$ and precipitated with by a solution of hydrochloric acid at $\mathrm{pH}<2$. The precipitate of humic acids were separated by centrifugation, washed on the filter with distilled water; the purified precipitate was further dried at the temperature of $60-70^{\circ} \mathrm{C}$. The thermal analysis of the samples of humic acid was performed in air in the temperature range of $20-1000^{\circ} \mathrm{C}$. On the basis of the thermolysis results, the content of carboxyl and hydroxyl groups in molecules of humic acids was determined and the ratio of aliphatic structures to cyclic ones in humic acids under consideration was calculated. The absorbance was determined by means of UV/Vis-spectroscopy. Its values were used to calculate the ratio of the amount of carbon in aromatic fragments to that in side radicals. The obtained data indicate a high proportion of aliphatic fragments in the structure of humic acids which confirms the data gained by thermal analysis. The total acidity of humic acids was determined by means of the barite method, it conforms with the values obtained by the thermal analysis of the samples under investigation.
\end{abstract}

Keywords: humic acids, functional groups, biopolymers, thermogravimetric analysis, UV/Vis-spectroscopy, heat effect.

DOI: $10.32434 / 0321-4095-2019-125-4-150-156$

\section{Introduction}

Humic substances are the main organic components of soil, water and solid combustible fossil fuels. A deficit humus balance requires the introduction of organic fertilizers into soils in addition to mineral fertilizers. Humates of sodium, potassium or ammonium, as water soluble salts of humic acids (HA), belongs to the known fertilizers $[1,2]$.

Due to the specific biological properties, humates are more accessible to the root system of the plants. Being biopolymers, they provide a high capacity to cationic and anionic metabolism and chelate ability. Also they can stimulate growth of the plants and provide nitrogen and ash nutrition [3]. Agents based on humic substances nowadays occupy an important place in the development of modern agricultural technologies; they can serve as nutrients for plant cultivation or play a role of physiologically active growth regulators [4,5].

Humic acids are high-molecular, mainly aromatic, oxycarboxylic acids, which contain methoxyl groups in the early stages of metamorphism. Condensed systems constitutes the basis of their structure, they include alicyclic and aromatic rings, side chains and functional groups in the nucleus and in the side chains. Fragments of the structure are bound with oxygen and methylene bridges. Humic acids belong to polyelectrolytes with weakly pronounced acid properties. Acid properties are caused by the presence of carboxyl and hydroxyl groups in their structure. Acid carboxylic and phenolic groups of humic acids form ion-type bonds with cations of metals, which is the reason for the dissociation of these compounds in aqueous solutions and, accordingly, the high solubility of humates in alkaline solutions. These functional groups also play

(c) I.V. Semeniuk, V.V. Kocubei, O.Ya. Karpenko, H.H. Midyana, O.V. Karpenko, V.V. Serheyev, 2019

I.V. Semeniuk, V.V. Kocubei, O.Ya. Karpenko, H.H. Midyana, O.V. Karpenko, V.V. Serheyev 
an important role in the interaction between humic acids and minerals, for example, the formation of complex iron or iron-phosphate bridges between the surface of a clay mineral particle and the HA molecule [6].

The aim of the present study is the determination of the structure and estimation of the functional properties of humic acids obtained from various sources.

\section{Material and methods}

The following raw materials were used to prepare HA: biohumus (TU U 13649334022-99) (I); peat from the Great Lubin deposit (II); commercial agent Humifirst (USA) manufactured from Leonardit (III); and black soil from Ternopil region (IV). To isolate humic substances, the raw materials were treated with a solution of alkali. The sedimentation of $\mathrm{HA}$ from a filtrate was carried out at $\mathrm{pH}<2$. After that the sediments were separated from the stock solution by centrifugation $(6000 \mathrm{rpm})$. The HA sediments were washed to remove sodium and chlorine ions. The resulting HAs were dried in a drying oven at $60-70^{\circ} \mathrm{C}$. The thermal analysis was carried out in the temperature range of $20-1000^{\circ} \mathrm{C}$ with free air access in the furnace using the Q-1500D derivatograph based on the Paulik-Paulik-Erdey system controlled by a personal computer. The rate of temperature increase was $5^{\circ} \mathrm{C} / \mathrm{min}$. The weight of the samples was ca. $80 \mathrm{mg}$. Aluminium oxide was used as a reference substance. The barite method was used to determine the overall HA acidity. UV/Vis absorption spectra of humic acids were recorded by means of the spectrophotometer UVmini-1240 (Shimadzu Corp., Japan). The measurement of adsorption of the investigated humic acids was carried out at the concentration of $0.001 \%$ (in $0.1 \mathrm{M}$ sodium hydroxide solution) using quartz cell $(10 \mathrm{~mm})$ in the wavelength region of $300^{-}$ $700 \mathrm{~nm}[7,8]$.

\section{Results and discussion}

Thermal analysis is one of the important methods to study organic compounds. It allows investigating not only the thermal stability of substances, but also the nature of the processes that occur when they are heated $[9,10]$.

The results of thermal analysis of samples, including thermogravimetry (TG), differential thermogravimetry (DTG) and differential thermal analysis (DTA), are presented in the form of thermograms (Figs. 1-4, Table 1). Using thermal analysis, the transformations of HA obtained from different raw materials were studied in air in the temperature range of $20-1000^{\circ} \mathrm{C}$.

In the temperature range of $20.0-151.1^{\circ} \mathrm{C}$, an emerging endothermic effect is observed on the DTA curves of samples, it corresponds to the removal of adsorption water. This process is accompanied by a loss of mass (8.6-11.1\%) in TG curves and clear extremum in DTG curves of the samples.

A further heating of the samples leads to the appearance of exothermic effects with different intensity in a DTA curve. The first exothermic effect that appears in the temperature range of 117.8$381.0^{\circ} \mathrm{C}$ is the least intense. It corresponds to the destruction and oxidation of peripheral hydrocarbon chains in molecules in the samples. This process is accompanied by a significant loss of mass (18.6$29.9 \%$ ) and the appearance of a deep extremum in

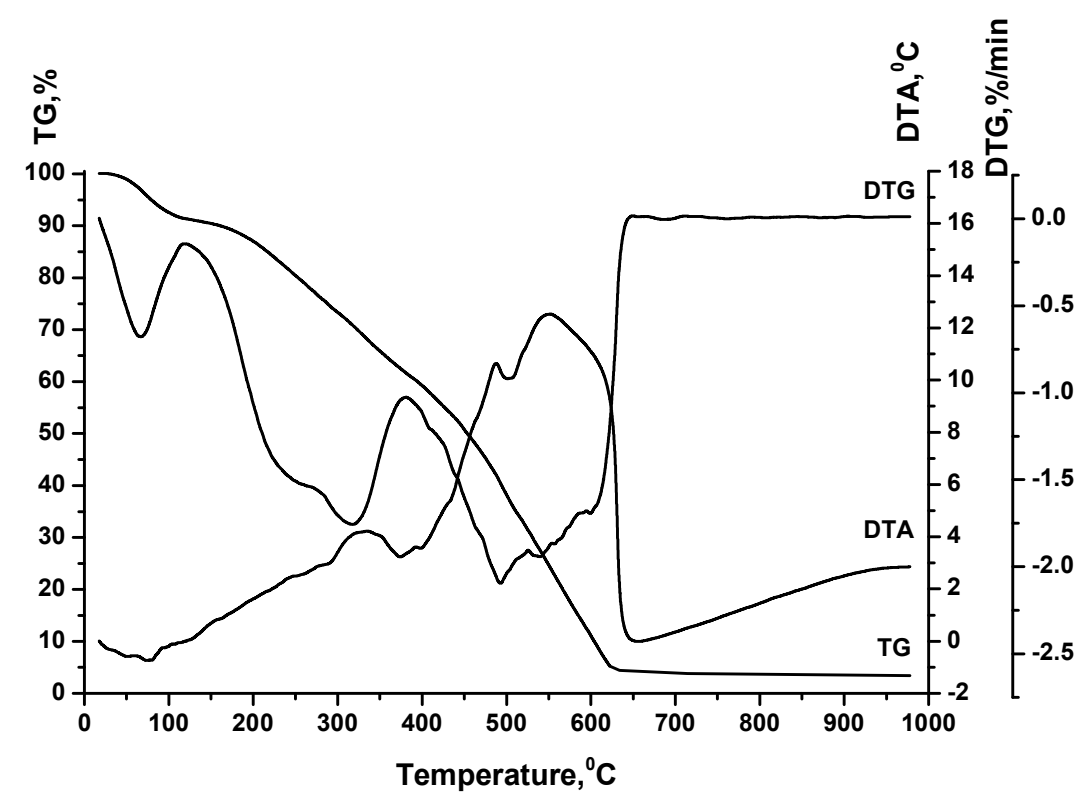

Fig. 1. Thermogram of humic acid from biohumus 


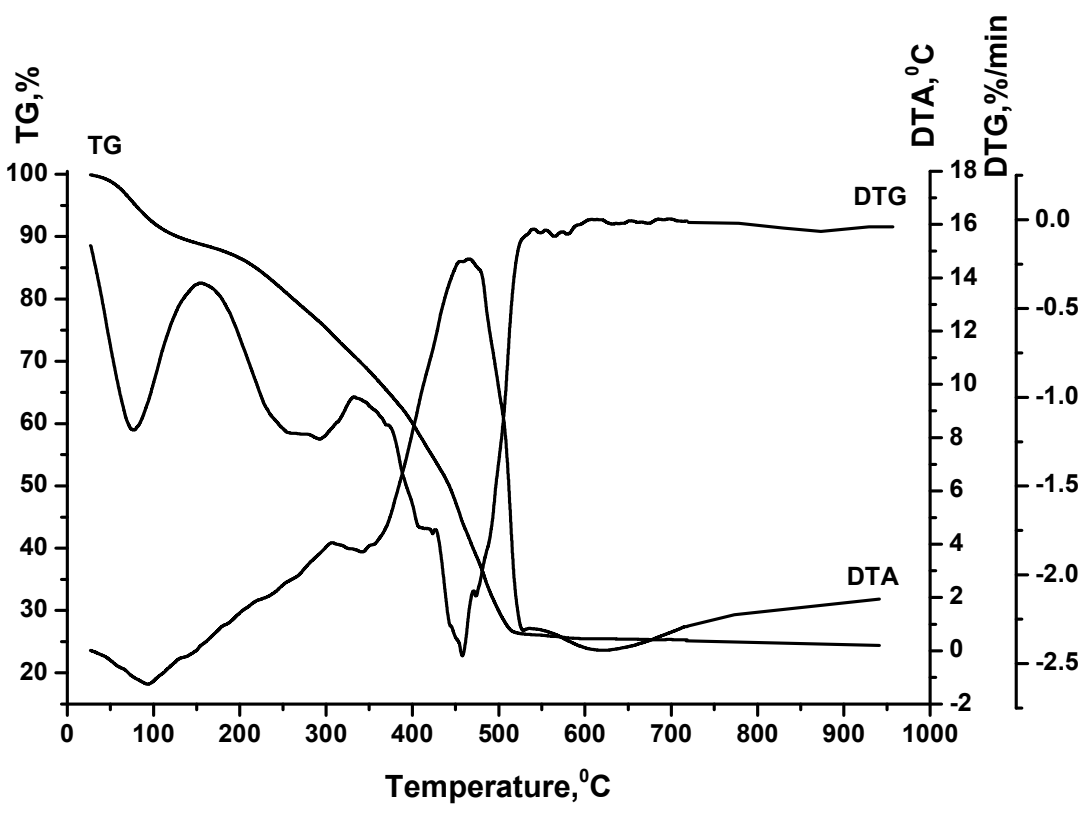

Fig. 2. Termogram of humic acid from peat

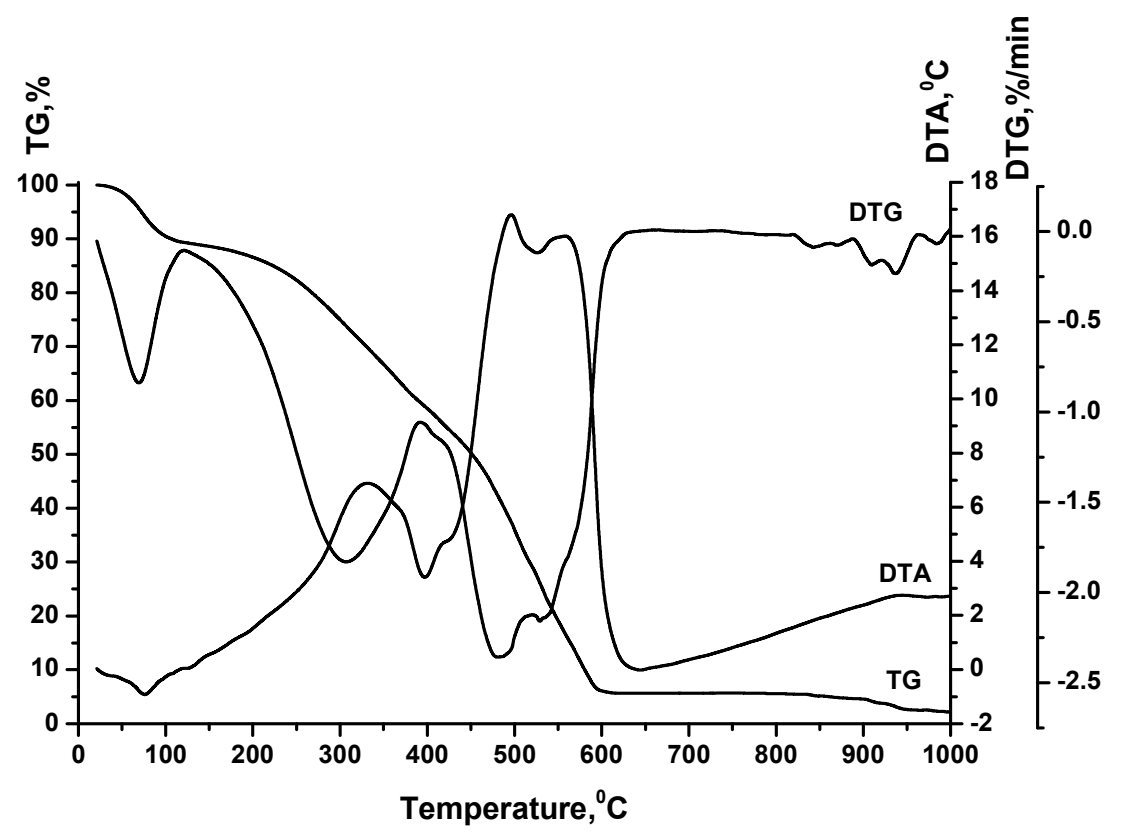

Fig. 3. Thermogram of humic acid from brown coal

DTG curves.

Further, a more extensively pronounced exothermic effect appears in DTA curves in the temperature range of $336.2-526.90^{\circ} \mathrm{C}$. It can be associated to the degradation of the aliphatic structures of the molecules in the samples, which is accompanied by the reaction of decarboxylation and dehydrogenation [10]. In this temperature range, the initial splitting of the central nuclear structures of the molecules in the samples is possible. This process is accompanied by an intense loss of the mass of the samples (27.4-44.1\%) and the appearance of deep extremum in DTG curves of the samples is observed.

The third intensive exothermic effect appears in DTA curves in the temperature range of 407.6$650.0^{\circ} \mathrm{C}$. It is attributed to the decomposition of the most stable cyclic fragments of molecules. There is combustion of carbon at temperatures close to $1000^{\circ} \mathrm{C}$ that was formed as a result of the thermal decomposition of samples. Unlike other samples, the samples of the acids from peat and black soil after heating to $1000^{\circ} \mathrm{C}$ had the highest residual mass 


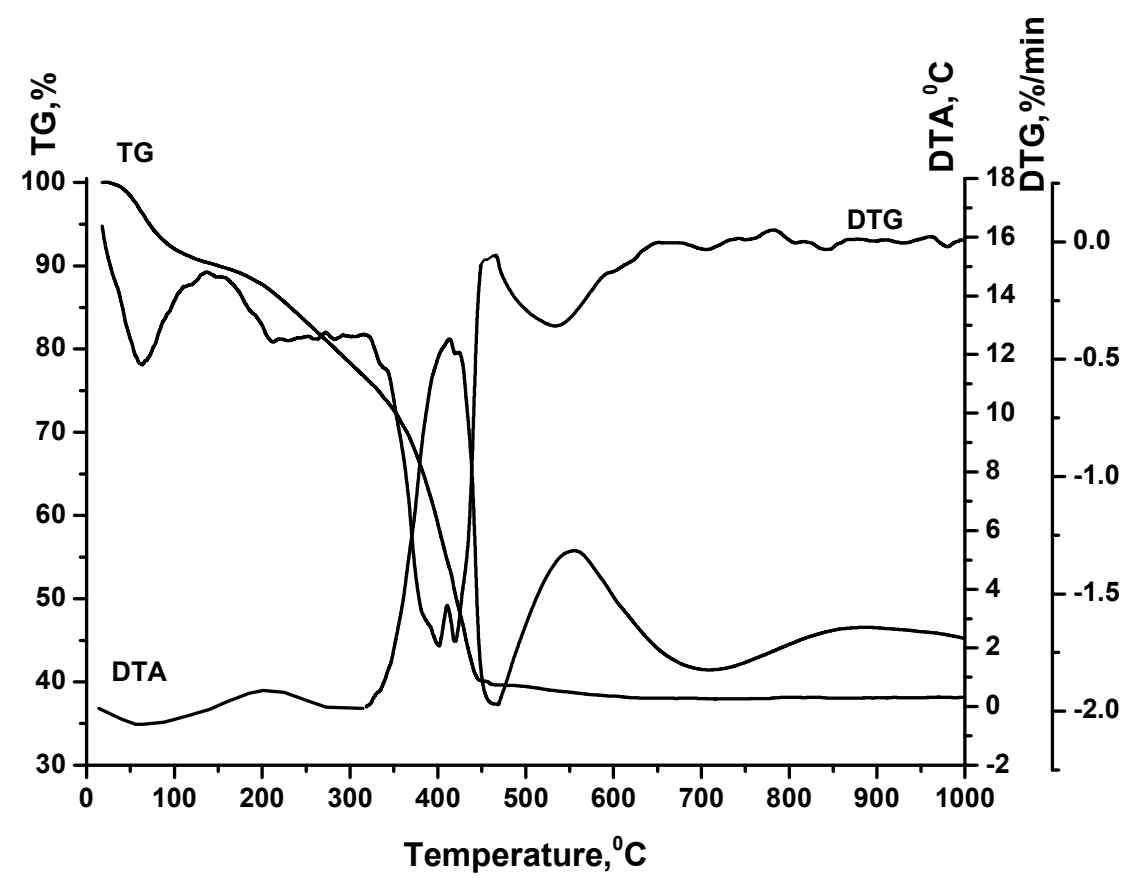

Fig. 4. Thermogram of humic acid from black soil

(23.2 and $38.5 \%$, respectively). This indicates the highest content of bound ions $\left(\mathrm{Fe}^{2+}, \mathrm{Cu}^{2+}, \mathrm{Zn}^{2+}\right.$, $\mathrm{Ca}^{2+}, \mathrm{Fe}^{3+}, \mathrm{Al}^{3+}$, etc.) in these samples.

The coefficient $\mathrm{K}$, which expresses the mass ratio of the aliphatic structures to cyclic ones in the sample molecules, was calculated from the mass losses in the low-temperature region (second stage of thermolysis) (Table 1) and the mass losses in the high-temperature interval (third and fourth stages). According to the results of the thermal analysis, it can be concluded that the molecules of humic acids, which are the part of samples of biohumus and brown coal, contain the highest share of aliphatic fragments.

The content of carboxyl and hydroxyl groups in the humic acid molecules, $\mathrm{R}$, was calculated based on the losses of the mass of samples at the third thermolysis stage and compared with the results obtained from the titration (Table 2). It should be noted that the $R$ values determined by thermogravimetric and titrimetric methods for HA isolated from I, II, and IV types of raw materials well coincide with each other. A somewhat greater difference is observed for brown coal. A better agreement of the data obtained by independent methods is observed for HA samples from peat and brown coal. The contents of carboxyl and hydroxyl groups determined for these samples by the titrimetric method are $19.2 \%$ and $29.1 \%$, respectively, (Table 2), whereas these values according to the results of thermal analysis are $20.6 \%$ and $27.4 \%$, respectively
Table 1

Results of thermal analysis of HA samples from different raw materials

\begin{tabular}{|c|c|c|c|c|}
\hline $\begin{array}{c}\text { Raw } \\
\text { material } \\
\text { type }\end{array}$ & Stage & $\begin{array}{l}\text { Temperature } \\
\text { range, }{ }^{0} \mathrm{C}\end{array}$ & $\begin{array}{c}\text { Mass } \\
\text { loss, } \\
\%\end{array}$ & $\mathrm{~K}^{*}$ \\
\hline \multirow{5}{*}{ Biohumus } & $\mathrm{I}$ & $20.0-124.5$ & 10.8 & \multirow{4}{*}{$63.1 / 20.7=3.04$} \\
\hline & II & $124.5-388.5$ & 29.3 & \\
\hline & III & $388.5-527.0$ & 33.8 & \\
\hline & IV & $527.0-636.0$ & 20.7 & \\
\hline & $\mathrm{V}$ & $636.0-1000.0$ & 3.1 & \\
\hline \multirow{5}{*}{ Peat } & $\mathrm{I}$ & $20.0-147.1$ & 9.9 & \multirow{4}{*}{$34.3 / 14.9=2.3$} \\
\hline & II & $147.1-319.2$ & 13.7 & \\
\hline & III & $319.2-410.1$ & 20.6 & \\
\hline & IV & $410.1-461.3$ & 14.9 & \\
\hline & $\mathrm{V}$ & $461.3-1000.0$ & 1.6 & \\
\hline \multirow{5}{*}{$\begin{array}{c}\text { Brown } \\
\text { coal }\end{array}$} & $\mathrm{I}$ & $20.0-117.8$ & 8.6 & \multirow{4}{*}{$57.3 / 28.7=2.00$} \\
\hline & II & $117.8-381.9$ & 29.9 & \\
\hline & III & $381.9-514.8$ & 27.4 & \\
\hline & IV & $514.8-654.0$ & 28.7 & \\
\hline & $\mathrm{V}$ & $654-1000.0$ & 1.1 & \\
\hline \multirow{5}{*}{ Black soil } & $\mathrm{I}$ & $20.0-150.0$ & 11.1 & \multirow{4}{*}{$-35.8 / 26.6=1.34$} \\
\hline & II & $150.0-332.6$ & 18.1 & \\
\hline & III & $332.6-431.0$ & 17.7 & \\
\hline & IV & $431.0-527.0$ & 26.6 & \\
\hline & $\mathrm{V}$ & $527.0-1000.0$ & 0.89 & \\
\hline
\end{tabular}

Note: $\mathrm{K}^{*}-$ is the coefficient of the ratio between aliphatic and cyclic structures. 
(Table 1). High discrepancies are observed for other HA samples.

As can be seen from Table 2, the values of the total content of acidic groups in the investigated HA samples from biohumus, brown coal, peat and black soil, which were determined by barite- and $\mathrm{Ca}$ acetate methods and by thermogravimetric analysis, do not differ significantly.

Table 2

The content of acid groups in samples of HA determined by the titrimetric method

\begin{tabular}{l|c|c|c}
\hline \multirow{2}{*}{$\begin{array}{c}\text { The source } \\
\text { of HA }\end{array}$} & \multicolumn{3}{|c}{$\begin{array}{c}\text { The content of acid groups in HA, } \\
\text { mmol/g (wt.\%) }\end{array}$} \\
\cline { 2 - 4 } & Carboxylic & Hydroxylic & Total \\
\hline Biohumus & $2.4(10.6 \%)$ & $9.2(15.7 \%)$ & $11.6(26.3 \%)$ \\
\hline Peat & $3.4(15.3 \%)$ & $2.3(3.9 \%)$ & $5.7(19.2 \%)$ \\
\hline Brown coal & $5.5(24.8 \%)$ & $2.5(4.3 \%)$ & $8.0(29.1 \%)$ \\
\hline Black soil & $3.5(15.6 \%)$ & $2.9(5.0 \%)$ & $6.4(20.6 \%)$ \\
\hline
\end{tabular}

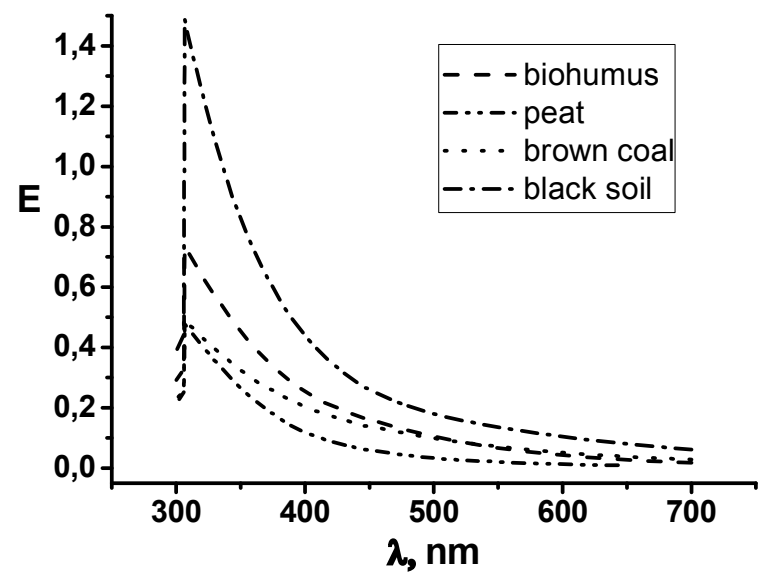

Fig. 5. UV/Vis spectra of humic acids obtained from various sources

The obtained results are in good agreement with the data of UV/Vis spectral analysis. Electronic spectra of $0.001 \%$ HA solutions in the ultraviolet and visible spectral regions are shown in Fig. 5 and Table 2. Figure 5 shows the electronic spectra of $0.001 \%$ of solutions of HA in UV and visible areas, which are characteristic of humic acids. UV/Vis spectra of humic acids look like descending curves without any absorption maxima. One of the diagnostic features of $\mathrm{HA}$ is the color ratio of solutions $\left(\mathrm{E}_{465} / \mathrm{E}_{650}\right)$ which shows the ratio between their optical density at 465 and $650 \mathrm{~nm}$, respectively. This ratio characterizes the coloration of the HA solutions, which is determined by the branching system of double bonds [7]. The coloration is caused by the presence of aromatic fragments in HA molecules, while the aliphatic side chains (polysaccharides, polypeptides and saturated hydrocarbons) do not cause the coloration of the solution. It was experimentally shown $[11,12]$ that the E values can be characterized by the ratio of the amount of carbon in aromatic structures to the amount of carbon in side radicals. Thus, the higher the aromaticity of the structures, the less is the ratio of $\mathrm{E}_{465} / \mathrm{E}_{650}$ [11]. The samples of biohumus and peat are distinguished by higher values of the chromaticity coefficients; this indicates a higher content of aliphatic fragments in these samples.

The values of $\mathrm{E}_{465} / \mathrm{E}_{650}$ ratio shown in Table 3 are in the range that is typical of humic acids [8].

Table 3

Spectral characteristics of the studied humic acids

\begin{tabular}{l|c|c|c}
\hline The source of HA & $\mathrm{E}_{465} / \mathrm{E}_{650}$ & $\mathrm{E}_{465}$ & $\mathrm{E}_{650}$ \\
\hline Biohumus & 5.48 & 0.1453 & 0.0265 \\
\hline Peat & 3.92 & 0.0878 & 0.0224 \\
\hline Brown coal & 3.51 & 0.1256 & 0.0358 \\
\hline Black soil & 2.88 & 0.2274 & 0.0789 \\
\hline
\end{tabular}

The coloration of the humic acids is mainly caused by the frame part of the molecules («nonhydrolyzing») with acid-containing groups, whereas the peripheral part of the molecules («hydrolyzing») does not practically cause the coloration. Therefore, the obtained characteristics allow estimating the contribution of the «non-hydrolyzing» part to the structure of the HA molecule. An increase in the chromaticity coefficients of humic acids is observed in the following range: black soil $<$ brown coal $<$ $<$ peat $<$ biohumus (Table 3 ). This may indicate a decrease in the content of aromatic fragments in their structures which is consistent with the data of thermogravimetric analysis. In our opinion, this may show a decrease in the molecular weight of humic acids in the above range and, accordingly, an increase in their ability to affect the permeability of plant cell membranes which can improve plant nutrition.

\section{Conclusions}

The total content of acid groups in the molecules of humic acids extracted from vermicompost, peat and chernozem was calculated by weight losses of samples at the third stage of thermolysis. The calculated data are in good agreement with those obtained using the titrimetric method.

The values of coefficients $\mathrm{K}$ showing the ratio of aliphatic parts to cyclic ones in the HA structure were calculated from the results of thermogravimetric analysis. They are higher than 1.0 confirming the aliphatic nature of the compounds under 
investigation.

According to the results of thermal and UV/Vis spectroscopy analyses, the content of linear fragments in the samples of humic acids extracted from different raw materials increases in the following range: black soil $<$ brown coal $<$ peat $<$ biohumus.

\section{REFERENCES}

1. Gorovaya A.I., Orlov D.S., Shcherbenko O.V. Humic substances. Structure, functions, mechanism of action, protector properties, ecological role. - K.: Naukova Dumka, 1995. - 302 p.

2. Piccolo A. The supramolecular structure of humic substances: a novel understanding of humus chemistry and implications in soil science // Adv. Agron. - 2002. - Vol.75. P.57-134.

3. Effects of humic acids from vermicomposts on plant growth / N.Q. Arancon, C.A. Edwards, S. Lee, R. Byrne // Eur. J. Soil Biol. - 2006. - Vol.42. - No. 1. - P.S65-S69.

4. Luchnik N.A., Ivanov A.E., Merkulov A.I. Sodium humates in the sowing of grain crops // Chem. Agric. - 1997. No. 2. - P.28-30.

5. Otsenka fiziologicheskoi aktivnosti guminovyk veshhestv okislennykh uglei / Butayev B.S., Zoltoyev E.V., Bodoyev N.V., Bykov I.P., Dashitsyrenova A.D. // Khimiya v Interesakh Ustoichivogo Razvitiya. - 2005. - Vol.13. - No. 4. - P.501-505.

6. de Melo B.A.G., Motta F.L., Santana M.H.A. Humic acids: structural properties and multiple functionalities for novel technological developments // Mater. Sci. Eng. C. - 2016. Vol.62. - No. 1. - P.967-974.

7. Characterization of humic substances by functional groups and spectroscopic methods / Eshwar M., Srilatha M., Bhanu Rekha K., Harish Kumar Sharma S. // Int. J. Curr. Microbiol. Appl. Sci. - 2017. - Vol.6. - No.10. - P.1768-1774.

8. Haddad G., El-Ali F., Mouneimne A.H. Humic matter of compost: determination of humic spectroscopic ratio $\left(\mathrm{E}_{4} / \mathrm{E}_{6}\right) / /$ Curr. Sci. Int. - 2015. - Vol.4. - No. 1. - P.56-72.

9. Metal-coordinated epoxy polymers with suppressed combustibility. Preparation technology, thermal degradation, and combustibility test of new epoxy-amine polymers containing the curing agent with chelated copper(II) carbonate / H. Lavrenyuk, V. Kochubei, O. Mykhalichko, B. Mykhalichko // Fire Mater. 2018. - Vol.42. - No. 3. - P.266-277.

10. Chuhareva N.V., Shishmina L.V., Novikov A.A. Vliyanie termoobrabotki torfa na sostav i svoistva guminovyk kislot // Khimiya Tverdogo Topliva. - 2003. - No. 4. - P.38-44.

11. Souza F., Braganca S.R. Extraction and characterization of humic acid from coal for the application as dispersant of ceramic powders // J. Mater. Res. Technol. - 2018. - Vol.7. - No. 3. P.254-260.

12. Orlov D.S., Sadovnikova L.K., Suhanova N.I. Khimiya pochv. - M.: Vysshaya shkola, 2005. - 561 p.

Received 01.02.2019

\section{ДОСЛІДЖЕННЯ СКЛАДУ ГУМІНОВИХ КИСЛОТ РІЗНОГО ПОХОДЖЕННЯ}

\section{І.В. Семенюк, В.В. Кочубей, О.Я. Карпенко, Г.Г. Мідяна,} О.В. Карпенко, В.В. Сергеєв

Методами термічного, титриметричного аналізів $i$ спектроскопії УФ і видимого діапазону здійснено дослідження особливостей будови молекул гумінових кислот, одержаних із різної сировини: біогумусу, торфу, бурого вугілля та чорнозему. Гумінові кислоти екстрагували із сировини водним розчином калію гідроксиду за температури $50^{\circ} \mathrm{C}$, осаджували розчином хлороводневої кислоти при рH<2. Гумінові кислоти, що випадали в осад відділяли центрифугуванням, промивали на фільтрі дистильованою водою, очищений осад висушували за температури 60-70 $\mathrm{C}$ до постійної маси. Термічний аналіз зразків гумінових кислот виконували у повітряному середовищі в інтервалі температур $20-1000^{\circ} \mathrm{C}$. За результатами термолізу розраховано вміст карбоксильних та гідроксильних груп у молекулах гумінових кислот, та коефіцієнт співвідношення аліфатичної $i$ циклічної структур досліджених гумінових кислот. Методом спектроскопії УФ і видимого діапазону визначено оптичну густину, за величиною якої розраховано співвідношення кількості Карбону в ароматичних фрагментах $i$ в бічних радикалах. Отримані значення вказують на переважаючу частку аліфатичних фрагментів в структурі гумінових кислот, що підтверджує дані, отримані методом термічного аналізу. Визначено загальну кислотність гумінових кислот титриметричним аналізом, за баритовою методикою. Отримані показники узгоджуються зі значеннями загальної кислотності, одержаними термічним аналізом досліджсуваних зразків гумінових кислот.

Ключові слова: гумінові кислоти, функціональні групи, біополімери, термогравіметричні аналізи, спектроскопія УФ і видимого діапазону, тепловий ефект.

\section{STUDY OF THE COMPOSITION OF HUMIC ACIDS OF DIFFERENT ORIGINS}

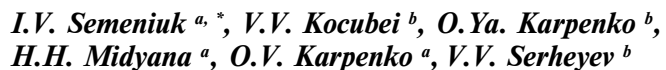

a Department of Physical Chemistry of Fossil Fuels of the L.M. Lytvynenko Institute of Physical-Organic Chemistry and Coal Chemistry of National Academy of Sciences of Ukraine, Lviv, Ukraine

b Lviv Polytechnic National University, Lviv, Ukraine

* e-mail: igorsem777@gmail.com

Thermal, titrimetric analysis and UV/Vis spectroscopy were used to study the structural features of molecules of humic acids prepared from different raw materials, such as biohumus, peat, brown coal, and chernozem. Humic acids were extracted from these material by aqueous solutions of potassium hydroxide at the temperature of $50^{\circ} \mathrm{C}$ and precipitated with by a solution of hydrochloric acid at $p H<2$. The precipitate of humic acids were separated by centrifugation, washed on the filter with distilled water; the purified precipitate was further dried at the temperature of $60-70^{\circ} \mathrm{C}$. The thermal analysis of the samples of humic acid was performed in air in the temperature range of $20-1000^{\circ} \mathrm{C}$. On the basis of the thermolysis results, the content of carboxyl and hydroxyl groups in molecules of humic acids was determined and the ratio of aliphatic structures to cyclic ones in humic acids under consideration was calculated. The absorbance was determined by means of UV/Vis-spectroscopy. Its values were used to calculate the ratio of the amount of carbon in aromatic fragments to that in side radicals. The obtained data indicate a high proportion of aliphatic fragments in the structure of humic acids which confirms the data gained by thermal analysis. The total acidity of humic acids was determined by means of the barite method, it conforms with the values obtained by the thermal analysis of the 
samples under investigation.

Keywords: humic acids; functional groups; biopolymers; thermogravimetric analysis; UV/Vis-spectroscopy; heat effect.

\section{REFERENCES}

1. Gorovaya A.I., Orlov D.S., Shcherbenko O.V., Humic substances. Structure, functions, mechanism of action, protector properties, ecological role. Naukova Dumka Publishers, Kyiv, 1995. $302 \mathrm{p}$.

2. Piccolo A. The supramolecular structure of humic substances: a novel understanding of humus chemistry and implications in soil science. Advances in Agronomy, 2002, vol. 75, pp. $57-134$

3. Arancon N.Q., Edwards C.A., Lee S., Byrne R. Effects of humic acids from vermicomposts on plant growth. European Journal of Soil Biology, 2006, vol. 42, pp. S65-S69.

4. Luchnik N.A., Ivanov A.E., Merkulov A.I. Sodium humates in the sowing of grain crops. Chemistry in Agriculture, 1997 , no. 2 , pp. $28-30$.

5. Butayev B.S., Zoltoyev E.V., Bodoyev N.V., Bykov I.P., Dashitsyrenova A.D. Otsenka fiziologicheskoi aktivnosti guminovykh veschestv okislennykh uglei [Evaluation of physiological activity of humic substances of oxidized coals]. Khimiya v Interesakh Ustoichivogo Razvitiya, 2005, vol. 13, no. 4, pp. 501-505. (in Russian).

6. de Melo B.A.G., Motta F.L., Santana M.H.A. Humic acids: structural properties and multiple functionalities for nove technological developments. Materials Science and Engineering: $C$, 2016, vol. 62, pp. 967-974.

7. Eshwar M., Srilatha M., Bhanu Rekha K., Harish Kumar Sharma S. Characterization of humic substances by functional groups and spectroscopic methods. International Journal of Current Microbiology Applied Sciences, 2017, vol. 6, no. 10, pp. 17681774.

8. Haddad G., El-Ali F., Mouneimne A.H. Humic matter of compost: determination of humic spectroscopic ratio $\left(\mathrm{E}_{4} / \mathrm{E}_{6}\right)$. Current Science International, 2015, vol. 4, no. 1, pp. 56-72.

9. Lavrenyuk H., Kochubei V., Mykhalichko O., Mykhalichko B. Metal-coordinated epoxy polymers with suppressed combustibility. Preparation technology, thermal degradation, and combustibility test of new epoxy-amine polymers containing the curing agent with chelated copper(II) carbonate. Fire and Materials, 2018, vol. 42, pp. 266-277.

10. Chuhareva N.V., Shishmina L.V., Novikov A.A. Vliyanie termoobrabotki torfa na sostav i svoistva guminovykh kislot [Effect of thermal treatment on the composition and properties of humic acids]. Khimiya Tverdogo Topliva, 2003, no. 4, pp. 38-44. (in Russian)

11. Souza F., Braganca S.R. Extraction and characterization of humic acid from coal for the application as dispersant of ceramic powders. Journal of Materials Research and Technology, 2018, vol. 7, pp. 254-260.

12. Orlov D.S., Sadovnikova L.K., Suhanova N.I., Khimiya poch $v$ [Chemistry of soils]. Vysshaya Shkola Publishers, Moscow, 2005. 561 p. (in Russian). 